\title{
PEMELIHARAAN BENIH PATIN JAMBAL DENGAN MEMANFAATKAN GRAVITASI DAN POSISI PEMASUKAN AIR
}

\begin{abstract}
Taufik Ahmad"), Lilis Sofiarsih"), Sutrisno"), dan Firdaus")
ABSTRAK

Sejak akhir 1990, para peneliti Balai Riset Perikanan Budidaya Air Tawar telah berhasil memproduksi benih patin jambal pada skala eksperimen di hatcheri. Di antara berbagai masalah yang dihadapi dalam upaya produksi massal benih patin jambal, kualitas air terutama konsentrasi DO dan temperatur air merupakan faktor kunci. Sebagai upaya mengatasi masalah tersebut, 3 posisi pemasukan air menggunakan gaya gravitasi diuji untuk mempertahankan DO sekitar jenuh. Akuarium ukuran $70 \times 50 \times 50 \mathrm{~cm}^{3}$, sebanyak 12 buah diisi air sampai kedalaman $30 \mathrm{~cm}$ dan ditebari 200 dan 500 benih $( \pm 0,3 \mathrm{~g}$ )/akuarium untuk masing-masing percobaan 1 dan 2 . Aliran air, $4 \mathrm{~L}$ /menit, pada kedua percobaan diset pada permukaan, tengah badan air, dan dasar sebagai perlakuan yang masing-masing memiliki 4 ulangan. Benih yang dipelihara dalam akuarium dengan aliran air di dasar bertumbuh pada laju $8,05 \% /$ hari dan lebih cepat dari benih dalam perlakuan aliran air permukaan dan tengah badan air, masing-masing $7,18 \%$ dan $7,35 \% /$ hari. Pada percobaan 1, semua benih mati pada hari ke-12 akibat serangan ich. Pada percobaan 2 , semua benih mati pada hari ke-17 akibat peningkatan kekeruhan air yang mencapai $>6.000$ $\mathrm{mg} / \mathrm{L}$ setelah hujan lebat 4 hari berturut-turut. Sintasan sebelum hari ke-17 berkisar $97,6 \%$ $98,6 \%$ dan tidak berbeda antar perlakuan. Tidak ada perbedaan kualitas air antar perlakuan. Gaya gravitasi tampak dapat dimanfaatkan untuk mempertahankan kualitas air tetap optimal dan dapat menggantikan fungsi aerator dalam upaya produksi benih patin jambal.
\end{abstract}

\begin{abstract}
Pangasius djambal fry production improvement in an optimum environment. By: Taufik Ahmad, Lilis Sofiarsih, Sutrisno, and Firdaus

Since late 1990, the researchers at Research Institute for Freshwater Aquaculture have successfully produced $P$. djambal fry in hatchery. Among the problems faced in mass fry production of $\boldsymbol{P}$. djambal, water quality more specifically, dissolved oxygen and water temperature are the key factors. To accommodate such a need, three different water flow positions in the aquaria using gravity force kept dissolved oxygen concentration in saturation. The aquaria, $70 \times 50 \times 50 \mathrm{~cm}^{3}$ each, filled with freshwater to $30 \mathrm{~cm}$ depth were stocked with 200 and 500 fry/aquarium for experiment 1 and 2, respectively. The water flow, $4 \mathrm{~L}$ minute, in both experiments was set at the surface, middle, and bottom water. The fry in the aquarium with bottom water flow grew at $8.05 \% /$ day and faster than the fry in the aquaria with surface and middle water flows which grew at $7.18 \%$ and $7.35 \% / d a y$, respectively. In experiment 1 , all fry died at day 12 due to white spot disease attack. In experiment 2 , al the fry died at day 17 due to extremely high total solid concentration, reaching more than $6,000 \mathrm{mg} / \mathrm{L}$ caused by 4 consecutive days heavy rain. The survival rate of the fry before the heavy rain was not different among treatments, ranging from $97.6 \%$ to $98.6 \%$. No different on water quality observed in each treatment, gravity force seems to be promising for maintaining suitable environment for $P$. djambal fry in aquaria and is able to replace the function of aerator to supply oxygen.
\end{abstract}

KEYWORDS: Pangasius djambal, gravity, dissolved oxygen, fry production

\section{PENDAHULUAN}

Di antara berbagai spesies ikan air tawar yang potensial untuk dibudidayakan secara komersial, patin menempati posisi tersendiri terutama untuk konsumen di Sumatera dan Kalimantan (Nasution et al., 1997; Asyari et al., 1997). Perkembangan teknologi budi daya kemudian mendorong penyebaran usaha produksi patin, terutama benihnya, ke daerah lain seperti Jawa. Upaya produksi benih ternyata berkaitan erat dengan pakan yang diberikan (Woynarovich \& Horvath, 1980), ketersediaan induk (Hardjamulia \& Atmawinata, 1986), serta kondisi lingkungan terutama kualitas air, lebih spesifik lagi konsentrasi DO. Komarudin (2000) melaporkan bahwa konsentrasi DO yang optimal bagi larva patin $3 \mathrm{mg} / \mathrm{L}$.

Peneliti pada Balai Riset Perikanan Budidaya Air Tawar, Bogor

Universitas Juanda, Bogor 
Kematian larva patin sering terjadi pada konsentrasi oksigen di bawah $3 \mathrm{mg} / \mathrm{L}$ walaupun gelondongannya (ukuran jari) masih dapat hidup pada konsentrasi DO sampai $0,6 \mathrm{mg} / \mathrm{L}$.

Pada umumnya untuk mempertahankan konsentrasi DO tetap optimal bagi kehidupan benih adalah dengan cara mengalihkan oksigen dari udara ke air menggunakan peralatan yang digerakkan oleh tenaga listrik (Ahmad, 1987). Karena itu, peningkatan tarif listrik berpengaruh terhadap biaya dan selanjutnya pada keuntungan usaha produksi benih patin yang saat ini baru berkembang. Cara pengalihan oksigen dari udara dengan memanfaatkan gaya gravitasi tampak sebagai salah satu alternatif yang dapat ditempuh untuk mempertahankan sintasan larva patin tetap tinggi tanpa harus menambah biaya produksi.

Pada penelitian ini gravitasi dimanfaatkan untuk memaksimalkan pengalihan oksigen dari udara melalui pengadukan dan pergantian air tanpa henti. Pengadukan air diperhitungkan sedemikian rupa hingga tidak bertentangan dengan sifat biologis larva yang dipelihara tetapi dapat mendistribusikan oksigen ke seluruh bagian wadah. DO yang merata pada sekitar konsentrasi jenuh di seluruh bagian wadah diharapkan mampu mencegah perlambatan tumbuh dan menurunkan mortalitas larva akibat anoksia. Pada gilirannya sintasan yang tinggi pada biaya produksi rendah diharapkan dapat meningkatkan keuntungan usaha produksi benih patin.

\section{BAHAN DAN CARA}

Penelitian diawali dengan pengumpulan induk siap mijah yang diangkut dari tempat penjual induk di Jambi sebagai pusat induk Pangasius djambal (Lagendre et al., 1999). Setelah diaklimatisasi dalam bak beton di Loka Riset Pemuliaan dan Teknologi Budidaya Perikanan Air Tawar, Sukamandi induk yang oocytesnya telah mencapai vitellogenesis akhir dirangsang supaya mijah dengan penyuntikan hormon ovaprim pada dosis $0,5 \mathrm{~mL}$ per kilogram induk yang diberikan dalam dua kali suntikan pada interval 8 jam (Lagendre et al., 2000). Induk jantan disuntik hormon ovaprim pada dosis $0,4 \mathrm{~mL}$ per kilogram pada saat bersamaan dengan penyuntikan kedua kali induk betina. Selama proses aklimatisasi dan setelah penyuntikan, induk diberi pakan pelet komersial pada dosis $3 \%$ bobot biomass yang diberikan 2 kali sehari.

Sperma dikeluarkan dengan cara pemijatan (striping) dan langsung ditampung dalam tabung tabung reaksi yang telah berisi larutan penonaktif sperma ( $\mathrm{NaCl} 175 \mathrm{nM})$. Setelah ovulasi, telur hasil pemijahan dicampur dengan sperma dari beberapa induk dan kemudian diinkubasi dalam corong McDonald setelah diperlakukan dengan tanah liat untuk mencegah telur lengket satu sama lain. Temperatur air dipertahankan pada kisaran $26^{\circ} \mathrm{C}$ $30^{\circ} \mathrm{C}$ dan konsentrasi DO pada sekitar jenuh

Percobaan 1. Larva dipelihara selama 20 hari dalam tangki larva kemudian ditebar kedalam akuarium penelitian berukuran $70 \times 50 \times 50 \mathrm{~cm}$ yang diisi air sampai $30 \mathrm{~cm}$ pada kepadatan 200 ekor/akuarium. Pakan buatan berkadar $40 \%$ protein diberikan 3 kali sehari sampai mencapai $5 \%$ bobot biomassa. Sisa pakan dan kotoran disipon setiap pagi hari sebelum pemberian pakan. Perlakuan yang diuji adalah dengan cara mengalirkan air sungai setelah melalui proses penyaringan dan oksigenasi (Gambar 1) untuk mempertahankan DO pada konsentrasi sekitar jenuh secara merata ke setiap bagian wadah. Dari tandon (Gambar 1), pada perlakuan pertama air dialirkan dalam bentuk semburan halus di permukaan air, pada perlakuan kedua dan ketiga air disemburkan seperti pada perlakuan pertama namun pada kedalaman berturut-turut 15 dan $30 \mathrm{~cm}$ (Gambar 2). Kedalaman air dalam tiap wadah $30 \mathrm{~cm}$ dan air dikeluarkan melalui dasar wadah untuk mengurangi penumpukan sisa pakan. Aliran air dihentikan selama 30 menit pada saat pakan diberikan. Setiap perlakuan memiliki 4 ulangan namun ulangan keempat digunakan untuk pengukuran pertumbuhan

Konsentrasi $\mathrm{DO}, \mathrm{pH}$, dan temperatur diukur dua kali sehari pada waktu pagi pukul 06.00 dan sore pukul 18.00 , total amonia diukur setiap minggu. Pada akhir penelitian, saat mortalitas massal terjadi, ikan ditimbang menggunakan electronic top loading balance berketelitian $0,05 \mathrm{~g}$ untuk menghitung kecepatan bertumbuh dalam laju bertumbuh harian (instantaneous daily growth rate) menggunakan rumus $W t=W o(1+0,01 a) t$

Percobaan 2. Sebagai upaya mempertinggi akurasi hasil prcobaan, dilakukan percobaan ulangan dengan perlakuan sama hanya padat penebaran ditingkatkan menjadi 500 ekor benih/akuarium. Ukuran akuarium sama seperti pada percobaan 1. Temperatur air dipertahankan di atas $26^{\circ} \mathrm{C}$ dengan cara menempatkan heater kapasitas 3.000 watt dalam pipa air dari tandon dan 8 lampu pijar 40 watt dalam bangunan tempat percobaan dilakukan. $\mathrm{NaCl}$ sebanyak $7 \mathrm{~g} / \mathrm{L}$ dan kalium permanganat pada dosis $4 \mathrm{mg} / \mathrm{m}^{3}$ ditambahkan pada air media dalam tandon secara bergantian dengan FMGO pada dosis $10 \mathrm{~mL} / \mathrm{m}^{3}$ tiap 3 hari untuk mencegah serangan penyakit bintik putih. Air dalam tandon diaerasi kuat untuk menjamin pasok oksigen yang mencukupi untuk seluruh unit percobaan.

\section{HASIL DAN BAHASAN}

Percobaan 1. Kualitas air pada semua unit percobaan berkisar pada konsentrasi optimal bagi 


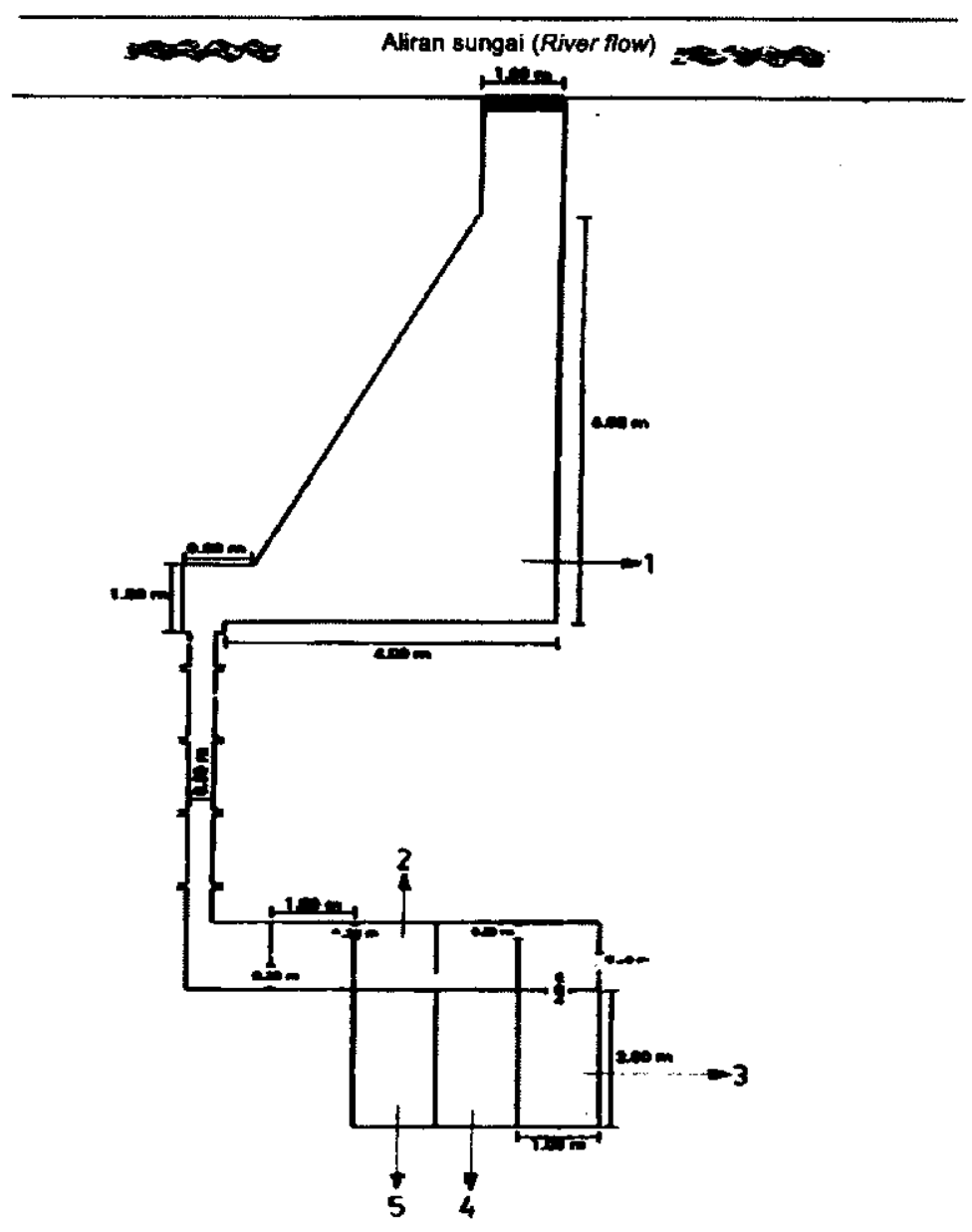

Gambar 1. Fasilitas perlakuan air: 1. Kolam Pistia sp., 2. Baffle diisi Pistia sp., 3. Tangki pengendap, 4. Filter serat dan pasir, 5. Tandon

Figure 1. Water treatment facilities: 1. Pistia sp. pond, 2. Baffle planted by Pistia sp., 3. Settlement tank, 4. Sand and fibre filter, 5. Reservoir

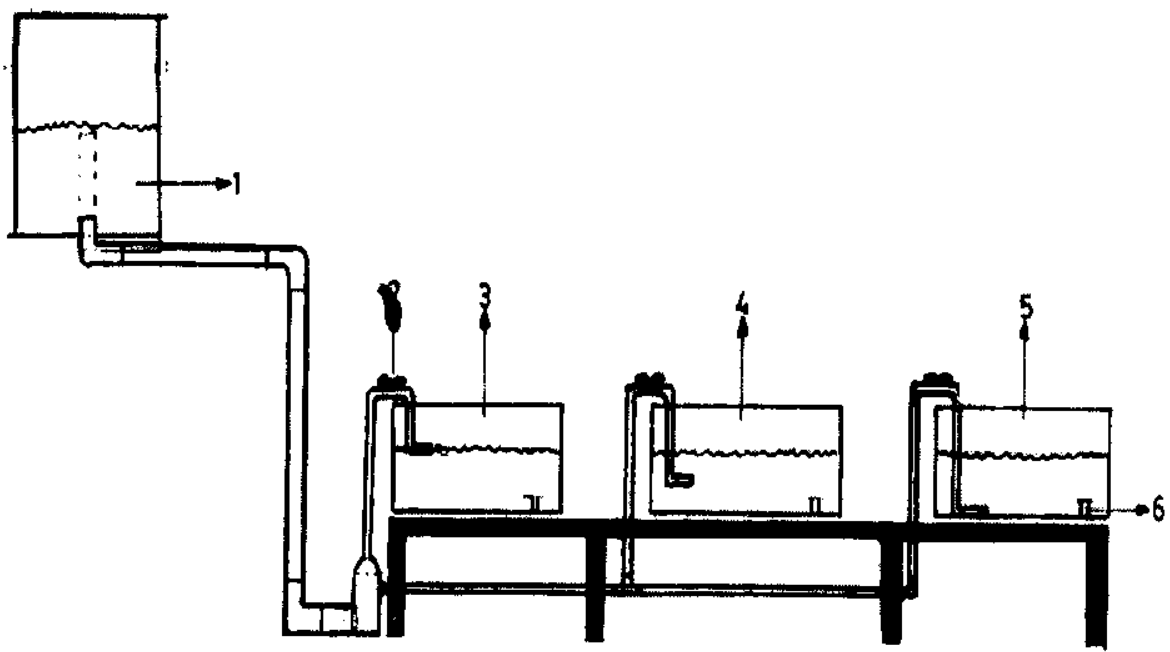

Gambar 2. Akuarium percobaan pasok air untuk benih patin jambal: 1. Tandon, 2. Katup pengatur air, 3. Aliran permukaan, 4. Aliran tengah badan air, 5. Aliran dasar, 6. Pembuangan air

Figure 2. Aquaria set up for Pangasius djambal experiment on water supply system: 1. Reservoir; 2 . Water flow adjustment valve; 3. Surface flow; 4. Middle flow; 5. Bottom flow; 6 . Water outlet 
kehidupan benih patin jambal. Konsentrasi DO relatif stabil pada sekitar konsentrasi jenuh, kecuali sekitar 3 jam pada waktu subuh, sesuai temperatur air yang dicatat pada hari yang sama (Tabel 1). Konsentrasi DO minimum yaitu jauh di bawah jenuh hanya terjadi selama 1-2 jam saat menjelang fajar. Pada $\mathrm{pH}$ tercatat sekitar $7-8$ selama penelitian, konsentrasi $\mathrm{NH}_{4}-\mathrm{N}$ berada pada kisaran yang tidak membahayakan, 0,113-0,194 $\mathrm{mg} / \mathrm{L}$, baik bagi pertumbuhan maupun sintasan benih patin jambal. Alkalinitas berada pada kisaran konsentrasi yang mampu mempertahankan kestabilan $\mathrm{pH}$. Secara umum, kualitas air yang merupakan salah satu tolok ukur lingkungan masih mampu mendukung kehidupan benih patin jambal selama penelitian berlangsung.

Konsentrasi $\mathrm{DO}$ dan suhu pada perlakuan aliran air di permukaan agak lebih tinggi daripada perlakuan baik aliran air di tengah maupun aliran air di dasar karena pengambilan sampel air dilakukan hanya di permukaan. Berdasarkan debit air yang dialirkan, air dalam tiap wadah terganti sempurna setelah lebih dari 3 jam sehingga tersedia cukup waktu untuk proses respirasi hewan uji serta dekomposisi sisa pakan dan kotoran menurunkan konsentrasi DO (Boyd, 1982) dalam kolom air pada setiap perlakuan kecuali pada perlakuan aliran air di permukaan. Dari fluktuasi oksigen terlarut harian,

Tabel 1. Kisaran nilai kualitas air dalam wadah benih patin jambal yang dilengkapi sistem aliran air berbeda Table 1. Water quality in Pangasius djambal aquaria at different water flowing systems

\begin{tabular}{|c|c|c|c|c|}
\hline \multirow{2}{*}{ Peubah (Variable) } & \multicolumn{4}{|c|}{$\begin{array}{c}\text { Posisi aliran air } \\
\text { Position of water inlet }\end{array}$} \\
\hline & $\begin{array}{l}\text { Permukaan } \\
\text { Surface }\end{array}$ & $\begin{array}{l}\text { Tengah } \\
\text { Middle }\end{array}$ & $\begin{array}{l}\text { Dasar } \\
\text { Bottom }\end{array}$ & $\begin{array}{l}\text { Tandon } \\
\text { Reservoir }\end{array}$ \\
\hline $\mathrm{DO}(\mathrm{mg} / \mathrm{L})$ & $2.60-6.66$ & $2.47-6.39$ & $2.08-6.39$ & \\
\hline \multicolumn{5}{|l|}{ Dissolved oxygen ( $m g / L)$} \\
\hline Suhu $\left({ }^{\circ} \mathrm{C}\right)$ & $26.0-30.0$ & $24.3-29.3$ & $25.0-29.6$ & \\
\hline \multicolumn{5}{|l|}{ Temperature $\left({ }^{\circ} \mathrm{C}\right)$} \\
\hline $\mathrm{pH}$ & $7.0-8.0$ & $7.0-8.0$ & $7.0-8.0$ & \\
\hline \multicolumn{5}{|l|}{$p H$} \\
\hline Alkalinitas (mg/L $\mathrm{CaO}_{3}$ ) & $53.49-56.46$ & $50.51-53.49$ & $50.52-53.49$ & \\
\hline \multicolumn{5}{|l|}{ Alkalinity $\left(\mathrm{mg} / \mathrm{L} \mathrm{CaCO}{ }_{3}\right)$} \\
\hline Amonia total $(\mathrm{mg} / \mathrm{L})$ & $0.138-184$ & $0.113-0.194$ & $0.103-0.166$ & \\
\hline Total ammonia $(\mathrm{mg} / \mathrm{L})$ & & & & \\
\hline
\end{tabular}

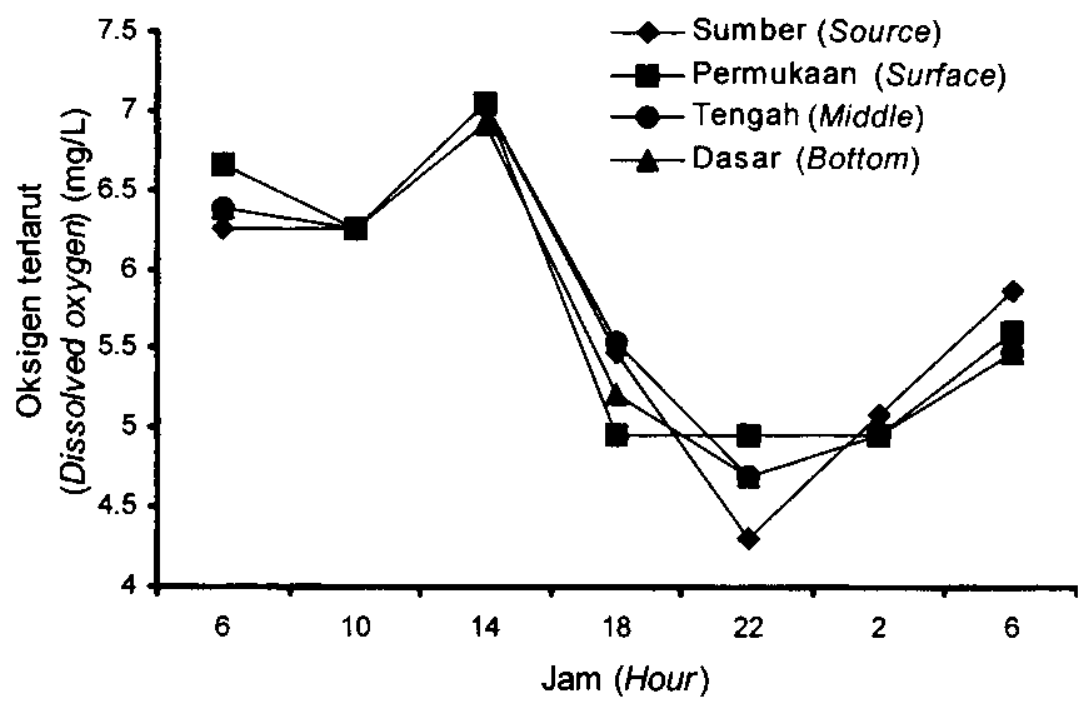

Gambar 3. Fluktuasi konsentrasi oksigen harian pada awal percobaan

Figure 3. Daily dissolved oxygen concentration fluctuation at the beginning of the experiment 
perbedaan posisi pemasukan air tidak berpengaruh terhadap konsentrasi DO dalam wadah (Gambar 3).

Konsentrasi DO merupakan peubah kualitas air utama yang mempengaruhi sintasan dan pertumbuhan patin jambal (Lagendre et al., 1999). Pada penelitian ini walaupun konsentrasi DO pada perlakuan air dialirkan di permukaan relatif sama dengan pada perlakuan air dialirkan di tengah kolom air dan di dasar, namun ikan uji pada perlakuan air dialirkan di dasar bertumbuh lebih cepat (Gambar 4). Berlainan dengan DO, suhu air berada pada kisaran lebih rendah dari kisaran optimal, $29^{\circ} \mathrm{C}-30^{\circ} \mathrm{C}$ (Lagendre et al., 1999), bagi patin jambal tetapi tidak sampai mengakibatkan perbedaan sintasan ikan sampai hari ke-12 (Tabel 2) saat ikan diserang ich.

Setelah hari ke-12 semua benih terserang white spot (bintik putih) dan pada hari ke-15 hampir semua hewan uji mati. Suhu air yang lebih rendah dari suhu optimal diduga memperlemah daya tahan ikan uji terhadap serangan parasit penyebab penyakit bintik putih, Ichthyophthirius multifiliis, yang dikenal juga sebagai ich hingga terjadi kematian massal dalam waktu singkat. Upaya menanggulangi masalah serangan ich dilakukan dengan menggunakan formaldehyde malachite green oxalate (FMGO), namun karena penyebaran penyakit sangat cepat upaya tersebut tidak berhasil baik. Mortalitas pada hari ke15 terjadi sama pada setiap perlakuan dan penelitian terpaksa dihentikan setelah sampel ikan uji diambil secara acak dari tiap perlakuan.

Sintasan hewan uji tidak berbeda nyata $(P>0,05)$ antar perlakuan namun pada perlakuan air dialirkan di dasar ikan uji bertumbuh lebih cepat $(P<0,05)$ dari pada perlakuan air dialirkan di atas (Tabel 2). Patin jambal menurut Lagendre et al. (2000) adalah penghuni bagian dasar sungai dan dilihat dari bentuk mulut merupakan benthic feeder, karena itu aliran air di dasar lebih sesuai untuk hewan uji dari aliran permukaan atau tengah kolom air.

Dikaji dari kualitas air, tampak konsentrasi oksigen terlarut (DO) menurun seiring dengan pertambahan bobot individu ikan uji (Gambar 5, 6, dan 7). Pada

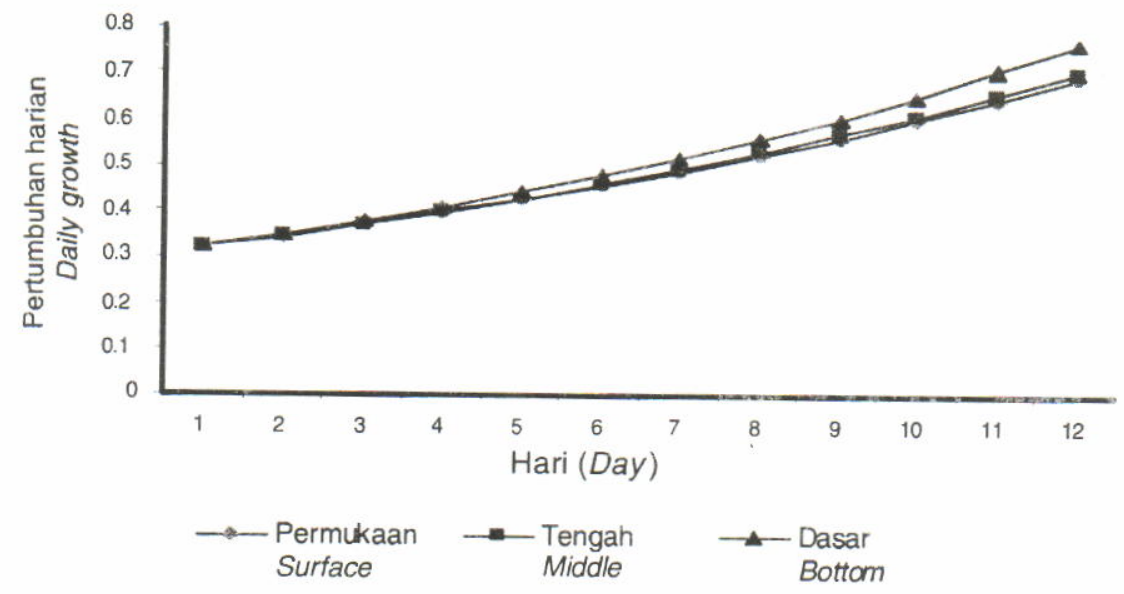

Gambar 4. Pertumbuhan harian benih patin jambal yang dipelihara pada posisi pemasukan air berbeda

Figure 4. Daily growth of Pangasius djambal juvenile raised at different water inlet positions

Tabel 2. Laju bertumbuh harian, sintasan, dan rataan pertambahan bobot $(\Delta \mathrm{G})$ benih patin jambal yang dipelihara selama 11 hari dalam aliran air berbeda

Table 2. Daily growth, survival rate, and average weght gain $(\Delta \mathrm{G})$ of Pangasius djambal juvenile raised in 11 days at different water inlet positions

\begin{tabular}{lccc}
\hline $\begin{array}{c}\text { Posisi aliran air } \\
\text { Position of water inlet }\end{array}$ & $\begin{array}{c}\text { Laju bertumbuh harian }(\%) \\
\text { Daily growth rate }(\%)^{*}\end{array}$ & $\begin{array}{c}\text { Sintasan }(\%) \\
\text { Survival rate }(\%)^{*}\end{array}$ & $\begin{array}{c}\text { Rataan Pertambahan bobot }(\mathrm{g}) \\
\text { Average weight gain }(\mathrm{g})^{*}\end{array}$ \\
\hline Permukaan (Surface) & $7.18^{\mathrm{a}}$ & $98.3^{\mathrm{a}}$ & $0.37^{\mathrm{a}}$ \\
Tengah (Moddle) & $7.31^{\mathrm{ab}}$ & $98.6^{\mathrm{a}}$ & $0.38^{\mathrm{a}}$ \\
Dasar (Bottom) & $8.05^{\mathrm{b}}$ & $97.6^{\mathrm{a}}$ & $0.45^{\mathrm{a}}$ \\
\hline
\end{tabular}

*Nilai yang diikuti superscript serupa dalam kolom yang sama tidak berbeda nyata $(p>0,05)$

*The values followed by similar superscript in the same column were not significantly different $(p>0.05)$ 
Gambar 5 disajikan fluktuasi DO dan laju pertumbuhan harian benih patin jambal pada wadah yang dialiri air di permukaan. Fluktuasi DO pada perlakuan air dialirkan di permukaan cenderung terjadi pada konsentrasi lebih tinggi dari pada perlakuan lain karena pengambilan sampel air dilakukan di permukaan. Diperlukan waktu untuk air yang dialirkan di tengah dan dasar kolom air untuk sampai ke permukaan tempat pengambilan sampel dilakukan. Pada waktu bersamaan terjadi proses respirasi ikan uji, penguraian sisa pakan dan kotoran, serta respirasi mikroba yang memerlukan oksigen, sehingga ketika air mencapai posisi pengambilan sampel konsentrasi DO pada perlakuan air dialirkan di tengah dan dasar kolom air telah berkurang dibanding konsentrasi DO dari sumber air yang mengalir di permukaan.
Fluktuasi DO pada perlakuan air dialirkan di tengah dan dasar kolom air terjadi pada konsentrasi lebih rendah dari pada perlakuan air dialirkan di permukaan, tetapi tidak mempengaruhi laju bertumbuh ikan uji (Gambar 4, 6, dan 7). Konsentrasi DO walaupun mencapai level terendah, sekitar $2,5 \mathrm{mg} / \mathrm{L}$, pada pagi hari ternyata tidak sampai menghambat pertumbuhan, sesuai dengan temuan Boyd (1982).

Berdasarkan laju bertumbuh harian, terbukti bahwa benih patin jambal yang dipelihara dalam akuarium dengan pasok air di dasar walaupun tampak bertumbuh lebih cepat namun pada tingkat kepercayaan $95 \%$ tidak berbeda nyata. Pada Tabel 2 terlihat bahwa walaupun pertambahan bobot mutlak hewan uji antar perlakuan tidak berbeda tetapi laju pertumbuhan harian ikan yang dipelihara

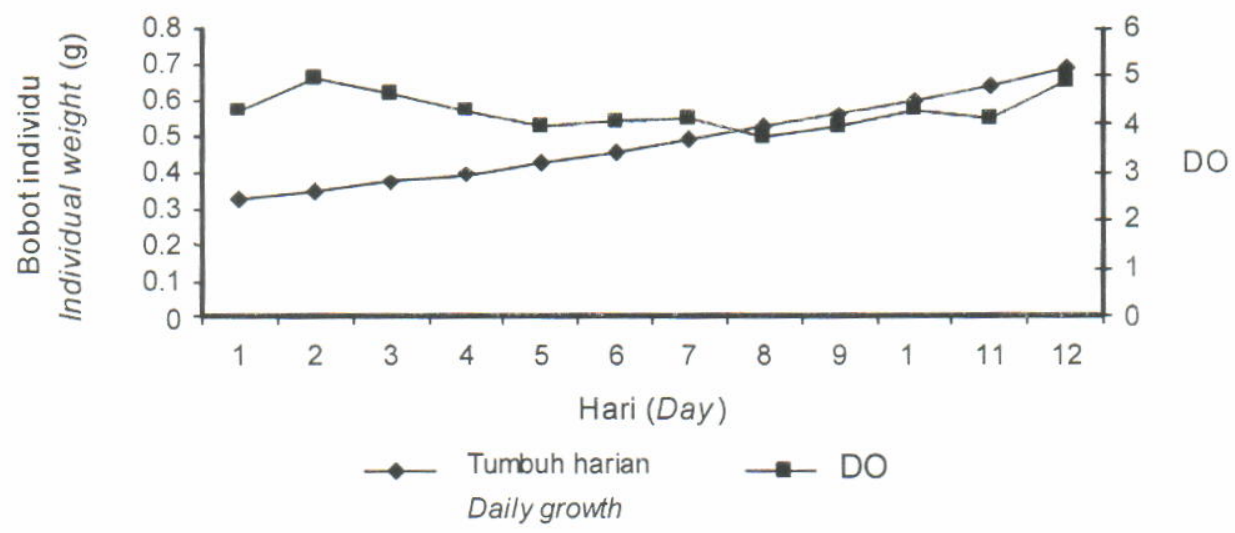

Gambar 5. Konsentrasi DO harian dan laju bertumbuh benih patin jambal dalam wadah yang dilengkapi aliran air permukaan

Figure 5. Daily dissolved oxygen concentration and daily growth of Pangasius djambal juvenile in the aquaria equipped with surface water inlet

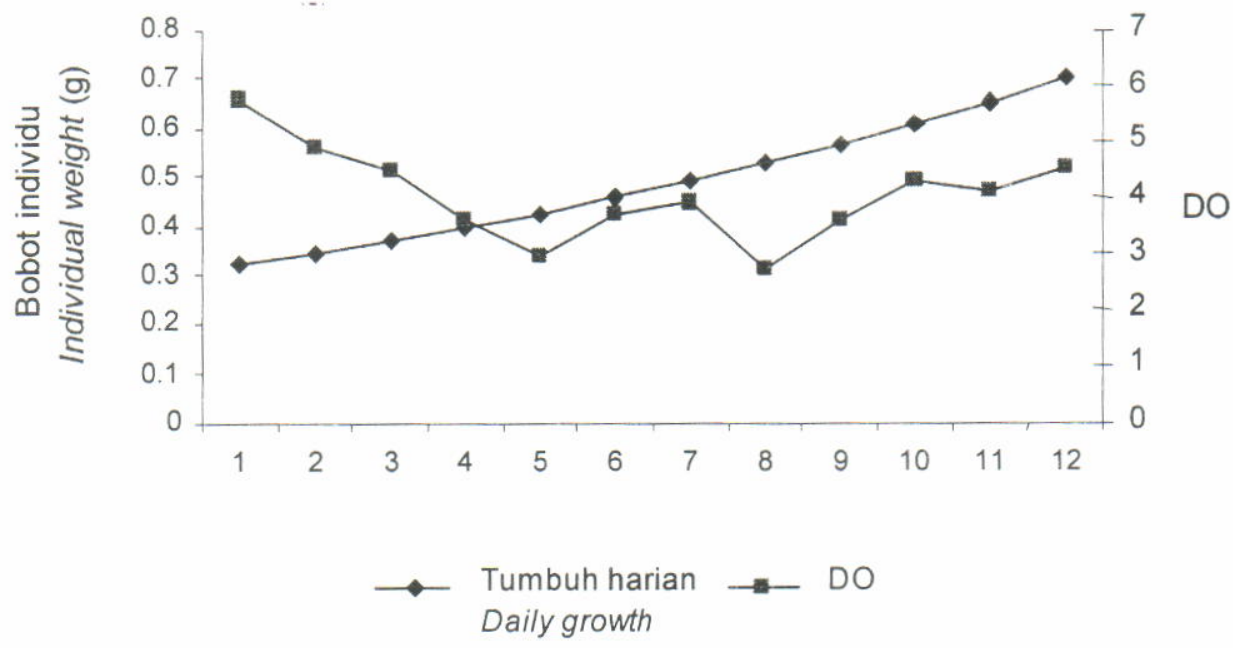

Gambar 6. Kor ntrasi DO harian dan laju bertumbuh patin jambal dalam wadah yang dilengkapi a in air di tengah badan air

Figure 6. Daily dissolved oxygen concentration and daily growth of Pangasius djambal juvenile in the aquaria equipped with middle water inlet 


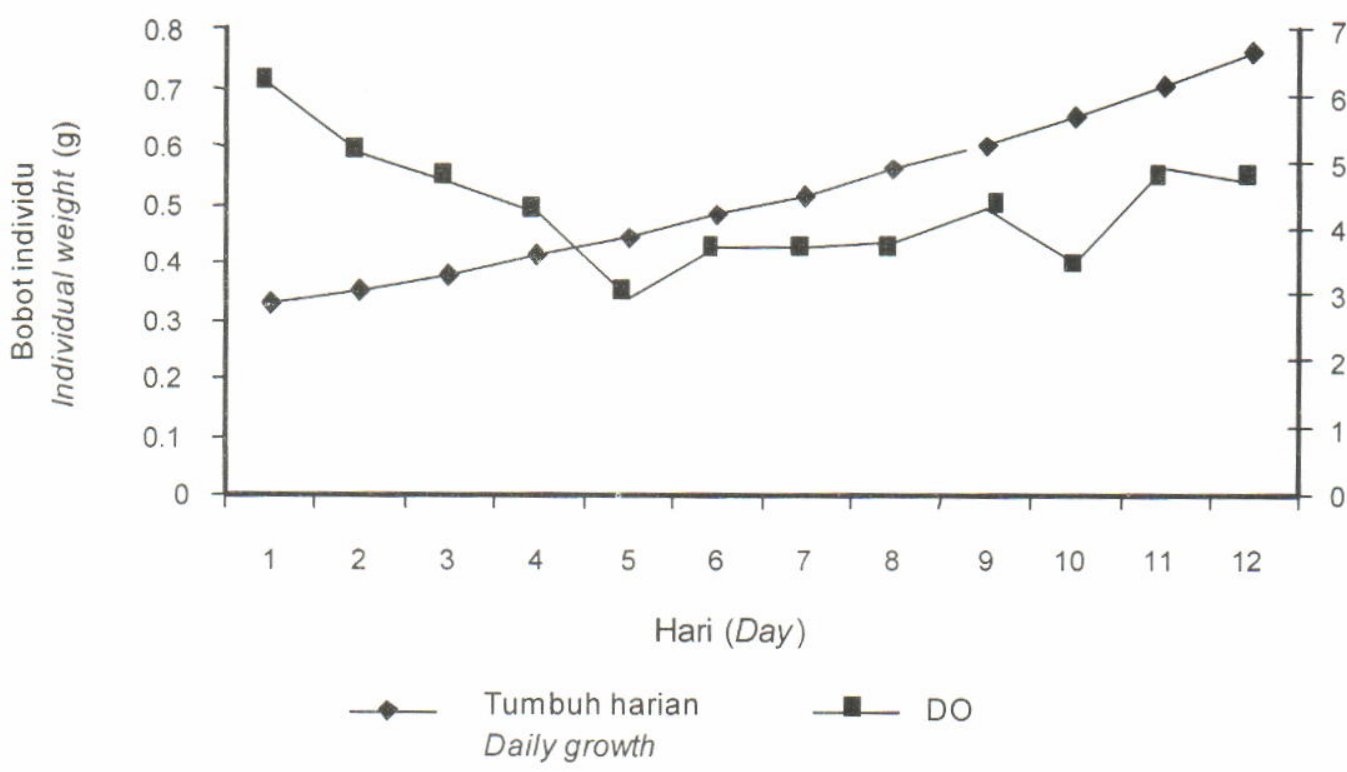

Gambar 7. Konsentrasi DO harian dan laju pertumbuhan patin jambal dalam wadah yang dilengkapi aliran air dasar

Figure 7. Daily dissolved oxygen concentration and daily growth of Pangasius djambal juvenile in the aquaria equipped with bottom water inlet

dalam wadah dengan pemasukan air di dasar walaupun hanya selama 12 hari lebih cepat dari yang dipelihara dalam wadah dengan pemasukan air di permukaan.

Pertumbuhan ikan uji pada semua perlakuan menurunkan konsentrasi DO dan penurunan konsentrasi DO terjadi lebih cepat pada perlakuan aliran air di dasar dan di tengah dari pada perlakuan aliran air di permukaan. Namun sebagai ikan penghuni sungai dan danau berarus lambat (Legendre et al., 2000), patin jambal lebih menyukai arus dasar, tampak dari tingkah laku ikan yang cenderung mengelompok di dasar wadah dan terbukti dari pertambahan bobot mutlak yang lebih tinggi pada perlakuan air dialirkan di dasar.

Dalam sehari, konsentrasi DO berfluktuasi dan mencapai konsentrasi minimum, sekitar $4 \mathrm{mg} / \mathrm{L}$, tidak lebih dari 2 jam walau pada waktu lewat tengah malam. Menurut Boyd (1982), konsentrasi DO rendah dalam jangka waktu singkat tidak mempengaruhi kehidupan ikan. Pada konsentrasi maksimum, DO juga tidak melampaui konsentrasi lewat jenuh yang dapat mengakibatkan gas bubble disease. Konsentrasi oksigen minimum setelah penelitian berjalan mencapai sekitar $2 \mathrm{mg} / \mathrm{L}$ (Tabel 1), respirasi ikan diperkirakan sangat berperan dalam pemanfaatan oksigen terlarut seperti tampak pada Gambar 4, 5, dan 6 yang memperlihatkan penurunan konsentrasi oksigen terlarut seiring peningkatan bobot individu ikan.

Hung et al. (1998) melaporkan bahwa benih $P$. bocourti, umur 2-1 hari, yang dipelihara dalam akuarium volume $50 \mathrm{~L}$ yang diaerasi dan airnya dialirkan dari sumur dengan kecepatan 0,4-0,5 L/menit tumbuh dengan kecepatan $20 \%$ /hari. Temperatur air pada penelitian tersebut berkisar $28^{\circ} \mathrm{C}-30^{\circ} \mathrm{C}$ dan konsentrasi DO dipertahankan di atas $5 \mathrm{mg} / \mathrm{L}$. Pada penelitian ini, konsentrasi $\mathrm{DO}$ yang berkisar 2,0 -6,5 $\mathrm{mg} / \mathrm{L}$ dan temperatur yang berkisar $26^{\circ} \mathrm{C}-29^{\circ} \mathrm{C}$ serta umur yang lebih tua, 20-32 hari, tidak memungkinkan ikan uji bertumbuh lebih dari $9 \% /$ hari.

Kanazawa (1994) menyarankan kecepatan air antara 350-700 mL/menit untuk pemeliharaan benih ikan sebelah, japanese flounder (Pararichthys olivaceus), yang merupakan penghuni dasar perairan. Pada penelitian ini, aliran air dipertahankan pada $4 \mathrm{~L} /$ menit karena ikan yang digunakan walaupun ikan dasar tetapi menghuni badan air bukan dasar perairan dan ukurannya juga lebih besar. Dikaji dari tingkah laku ikan uji yang menyebar dalam wadah dan berenang tanpa terpengaruh aliran air, kecepatan aliran air yang diterapkan diperkirakan tidak berpengaruh terhadap laju bertumbuh.

Faktor lingkungan yang secara nyata berpengaruh terhadap sintasan adalah pertumbuhan populasi yang cepat dari ich sampai mampu menyebabkan kematian massal dengan cepat. Taukhid et al. (2002) melaporkan bahwa ich tidak dapat berkembang pada temperatur di atas $29^{\circ} \mathrm{C}$. Pada penelitian ini temperatur air maksimum memang mencapai $29^{\circ} \mathrm{C}$ namun temperatur minimurn dapat mencapai $24^{\circ} \mathrm{C}$ yang merupakan temperatur ideal bagi pertumbuhan populasi ich. 
Upaya pencegahan perkembangan populasi ich tampaknya perlu dilakukan dengan baik untuk mencegah kematian massal akibat penyakit bintik putih. Agar tidak menambah biaya terlalu tinggi sebaiknya upaya pencegahan dilakukan dengan penambahan garam dapur $(\mathrm{NaCl})$ sebanyak $7 \mathrm{~g} / \mathrm{L}$. Bahan kimia seperti formalin malachite green oxalate, dan kalium permanganat kalau mungkin dihindari kecuali dalam keadaan darurat.

Percobaan 2. Kematian ikan uji tidak terjadi sampai hari ke-6 setelah penebaran. Sampai hari ke-11 kematian yang terjadi bahkan masih di bawah $1,0 \%$ (Gambar 8), sebagai hasil pencegahan ich menggunakan $\mathrm{NaCl}, \mathrm{FMGO}$ (formalin malachite green oxalate) dan PK (Kalium permanganat) secara bergantian setiap 3 hari, dan ikan uji sehat serta makan dengan rakus. Tidak terdapat sisa pakan yang berarti pada setiap kali pemberian pakan sampai hari ke-11 saat terjadi hujan lebat yang terus berlangsung sampai hari ke-15.

Mulai hari ke-12 kualitas air memburuk akibat peningkatan kekeruhan dan konsentrasi padatan

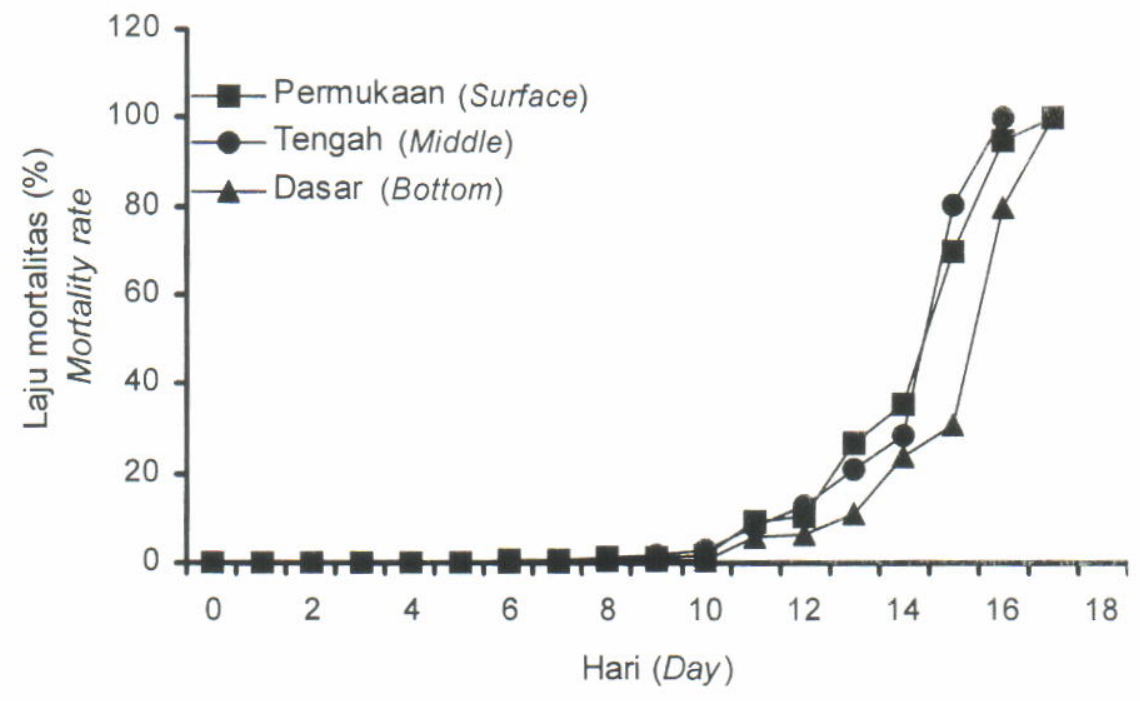

Gambar 8. Laju mortalitas benih patin jambal pada posisi aliran air berbeda

Figure 8. Mortality rate of Pangasius djambal juvenile raised in different water inlet positions

Tabel 3. Pertumbuhan benih patin jambal yang dipelihara pada posisi aliran air berbeda $(n=20)$ Table 3. The growth of Pangasius djambal juvenile raised in different water inlet positions $(n=20)$

\begin{tabular}{|c|c|c|c|c|}
\hline \multirow{2}{*}{$\begin{array}{l}\text { Peubah } \\
\text { Variable }\end{array}$} & \multirow{2}{*}{$\begin{array}{c}\text { Posisi aliran air } \\
\text { Water inlet position }\end{array}$} & \multicolumn{3}{|c|}{$\begin{array}{l}\text { Pengamatan (minggu) } \\
\text { Observation (week) }\end{array}$} \\
\hline & & 0 & 1 & 2 \\
\hline Panjang total (mm) & Permukaan & & & \\
\hline \multirow[t]{5}{*}{ Total length $(\mathrm{mm})$} & Surface & 30.0 & 37.5 & $47.0^{\mathrm{a}}$ \\
\hline & Tengah & & & \\
\hline & Middle & 30.0 & 37.5 & $47.0^{a}$ \\
\hline & Dasar & & & \\
\hline & Bottom & 30.0 & 43.0 & $49.0^{a}$ \\
\hline Bobot $(\mathrm{g})$ & Permukaan & & & \\
\hline \multirow[t]{5}{*}{ Weight (g) } & Surface & 0.45 & 0.62 & $0.94^{b}$ \\
\hline & Tengah & & & \\
\hline & Middle & 0.45 & 0.60 & $1.05^{b}$ \\
\hline & Dasar & & & \\
\hline & Bottom & 0.45 & 0.83 & $1.12^{b}$ \\
\hline
\end{tabular}

*Nilai yang diikuti superscrpit serupa dalam kolom dan lajur yang sama tidak berbeda nyata

*The values followed by similar superscript in the same column and row were not significantly different 
terlarut mencapai $6.340 \mathrm{mg} / \mathrm{L}$ pada hari ke-15 yang merupakan peningkatan dari hari ke-14 dan ke-13 yang sudah mencapai 5.240 dan $3.180 \mathrm{mg} / \mathrm{L}$. Filter dan baffle yang dirancang pada saluran masuk reservoir ternyata tidak mampu mengatasi konsentrasi padatan terlarut yang demikian tinggi 3 hari berturutturut. Berdasarkan pengamatan di bawah mikroskop, insang terutama gill fillament semua ikan yang mati mulai hari ke-11 terselimuti partikel lumpur. Temuan ini memperkuat dugaan ikan mati akibat kekurangan oksigen, terlihat dari kecenderungan ikan megapmegap di permukaan air. Serangan penyakit bintik putih juga memperlihatkan gejala yang sama, namun berdasarkan pengamatan di bawah mikroskop sampai pembesaran $40 x$ tidak terdapat tanda serangan ich seperti bercak putih pada insang dan kulit. Padatan tersuspensi yang mencapai $3.180 \mathrm{mg} / \mathrm{L}$ tampaknya masih tidak dapat ditolerir walaupun patin jambal merupakan ikan penghuni sungai.

Laju bertumbuh ikan uji pada penelitian kedua tidak berbeda dengan pada penelitian pertama, ikan yang dipelihara dalam akuarium dengan aliran air di dasar bertumbuh lebih cepat dari ikan dalam akuarium lainnya (Tabel 4). Perbedaan laju bertumbuh tersebut bukan diakibatkan oleh perbedaan jumlah ikan karena ikan dalam akuarium dengan aliran di dasar tetap lebih banyak dari ikan dalam akuarium dengan aliran air baik di tengah maupun di permukaan sampai penelitian berakhir. Sebagai ikan penghuni dasar sungai patin jambal lebih menyukai aliran air di dasar, selain itu posisi mulut patin jambal juga lebih sesuai untuk memangsa makanan yang ada di dasar daripada yang ada di permukaan. Feeding behaviour dan kebiasaan patin jambal tampaknya tidak berubah walaupun dipelihara dalam tempat terbatas, karena itu akuarium yang dirancang memiliki aliran air di dasar lebih sesuai dari pada akuarium yang dirancang memiliki aliran air di permukaan atau di tengah.

\section{KESIMPULAN}

Kegiatan penelitian tidak dapat diselesaikan sesuai rencana karena faktor alam yang sulit diperhitungkan namun berdasarkan temuan yang diperoleh dari kedua percobaan yang saling memperkuat dapat disimpulkan bahwa aliran air di dasar wadah masih lebih baik bagi kehidupan patin jambal dari aliran baik di permukaan maupun ditengah badan air. Aliran air sampai $4 \mathrm{~L} /$ menit sebagai hasil gaya gravitasi masih dapat mendukung kehidupan patin jambal tanpa bantuan peralatan listrik seperti aerator. Faktor lingkungan yang perlu diperhatikan pada pemeliharaan benih patin jambal adalah temperatur, harus $29^{\circ} \mathrm{C}-30^{\circ} \mathrm{C}, \mathrm{DO}$ sekitar jenuh, dan padatan tersuspensi $<300 \mathrm{mg} / \mathrm{L}$ (sama seperti sebelum hujan lebat).

\section{UCAPAN TERIMA KASIH}

Penelitian ini dapat berjalan atas bantuan Saudara Kutub yang memberi pakan ikan uji secara tepat waktu tiap hari dan SaudariAtin yang tiap pagi membersihkan akuarium serta menyipon sisa pakan. Jerih payah mereka sangat dihargai. Dana penelitian ini berasal dari APBN Tahun Anggaran 2003.

\section{DAFTAR PUSTAKA}

Ahmad, T. 1987. Evaluation of Paddle Wheel Aerator Design for Use in Fish Culture Ponds. A Dissertation for Doctor of Philosophy, Auburn University, Alabama, USA, $94 \mathrm{pp}$.

Boyd, C.E. 1982. Water Quality Management for Pond Fish Culture. Elsevier Scientific Publishing Company, New York, USA.

Asyari, Z. Arifin, dan A.D. Utomo. 1997. Pembesaran ikan patin (Pangasius pangasius $\mathrm{HB}$ ) dalam sangkar di Sungai Musi, Sumatera Selatan. J. Pen. Per. Indonesia, 3 (2): 83-90.

Hardjamulia, A. dan S. Ardiwinata. 1986. Tehnik hipofisasi beberapa jenis ikan air tawar. Dalam Fuad Cholik (Ed.), Prosiding Lokakarya Nasional Teknologi Tepat Guna Bagi Pengembangan Perikanan Budidaya Air Tawar. Bogor 28-31 Juni 1980. Balai Penelitian Perikanan Air Tawar, Bogor.

Hung, Le Thanh, Nguyen anh Tuan, Nguyen van Hien and P. Cacot. 1998. Larval rearing of the Asian catfish, Pangasius bocourti (Siluriformes, Pangasiidae): Artemia alternative feeding and weaning time. In The biological diversity and Aquaculture of Clariidae and Pangasiid catfishes in South East Asia, M. Lagendre and A. Parisele (Eds.). Proceedings of The Mid-Term Workshop of The Catfsh Asia Project, 11-15 May 1998. Cantho, Vietnam, p. 127-136.

Kanazawa, A. 1994. Nutrition of larval fish. In Nutrition and utilization Technology in Aquaculture, C. Lim and D. J. Sessa (Eds.). AOCS Press, Champaign, Illinois, USA, p. 50-57.

Komarudin, O. 2000. Ikan patin jambal andalan Indonesia. Warta Penelitian dan Pengembangan Pertanian, 22 (3): 1-2.

Lagendre, M., L. Pouyaud, J. Stembrouck, R. Gustiano, A.H. Kristanto. J. Subagja, O. Komaruddin, Sudarto, and Maskur. 2000. Pangasius djambal: A new candidate species for fish culture in Indonesia. IARD Journal, 22 (1): 1-14.

Lagendre, M., J. Slembrouck, J. Subagja, and O. Komarudin. 1999. Success of artificial propagation of the fast growing local "Patin", Pangasius djambal. Warta Penelitian Perikanan Indonesia, 5: 24

Nasution, Z., E. Dharyati, dan Rupawan. 1997. Adopsi teknologi budidaya ikan patin pada masyarakat tani di Desa Mariana, Sumatera Selatan. J. Pen. Per. Indonesia, 3(2): 35-40.

Taukhid, D. Bastiawan, dan O. Komaruddin. 2002. Ichthyophthirius multifiliis "ich". Laboratorium Kesehatan Ikan. Balai Riset Perikanan Budi daya Air Tawar. 
Woynarovich, E. and L. Hovarth. 1980. The artificial propagation of warmwater fish A Manual for
Extension FAO. Fisheries Technical Paper, No. 2091, $385 \mathrm{pp}$. 